\title{
POSTPRINT
}

Nadine Proske

Arnulf Deppermann

\section{Right-dislocated complement clauses in German talk-in-interaction}

(Re-)specifying propositional referents of the demonstrative pronoun das

\begin{abstract}
This contribution deals with right-dislocated complement clauses with the subordinating conjunction dass ('that') in German talk-in-interaction. The bi-clausal construction we analyze is as follows: The first clause, in which one argument is realized by the demonstrative pronoun das ('this/that'), is syntactically and semantically complete; the reference of the pronoun is (re-)specified by adding a dass-complement clause after a point of possible completion (e.g., aber das hab ich nich MITbekommen. (0.32) dass es da so YOUtubevideos gab. ('But I wasn't aware of that. That there were videos about that on YouTube.'). The first clause always performs a backward-oriented action (e.g., an assessment) and the second clause (re-)specifies the propositional reference of the demonstrative, allowing for a (strategic) perspective shift. Based on a collection of 93 cases from everyday conversations and institutional interactions, we found that the construction is used close to the turn-beginning for referring to and (re-)specifying (parts of) another speaker's prior turn; turn-internal uses tie together parts of a speaker's multi-unit turn. The construction thus facilitates an incremental constitution of meaning and reference.
\end{abstract}

Keywords: right-dislocation, complementizer, German, demonstrative

\section{Introduction}

This contribution ${ }^{1}$ deals with a bi-clausal construction in spoken German that has not been empirically investigated to date. It consists of a main clause with a

1. We thank the editors and Elwys De Stefani for their comments on earlier versions of this paper. We also thank our colleagues Julia Kaiser, Thomas Spranz-Fogasy, and Jörg Zinken for helpful discussions. Thanks to Allison Adelman for checking our English. 
demonstrative pronoun (das 'that') and a complement clause with the complementizer dass ('that'), as in the following example: aber das hab ich nich MITbekommen. (0.32) dass es da so YOUtubevideos gab. ('But I wasn't aware of that. That there were videos about that on YouTube.). In the literature, the demonstrative in the first clause is seen as co-referential with the 'right-dislocated' complement clause, that is, it is seen as a cataphoric device (see Section 2). Yet, the literature stresses that the neuter demonstrative das can have various uses, which include anaphoric, cataphoric, anadeictic, and catadeictic reference (Ahrenholz, 2007). From an online-perspective on talk-in-interaction, this raises the question of how the pronoun reference within a right dislocation construction is established: Upon production of the first clause, the recipient cannot know that the speaker will add a complement clause. Sometimes it is even obvious (because of pauses, hesitations, and prosodic features) that the speaker has not planned the complement clause in advance. Therefore, the demonstrative cannot be interpreted as cataphoric upon its occurrence; rather, it must first be interpreted like any other demonstrative. Once the second clause is produced, though, the interpretation of the pronoun must be adjusted according to the content of the complement clause and the first clause becomes retrospectively interpretable as a matrix clause. The right dislocation construction we discuss in this article is thus intrinsically emergent, because the reanalysis of the anaphoric demonstrative as a cataphoric pronoun occurs online, that is, while its production and reception are in progress. Points of completion on different levels of linguistic description (syntax, prosody, semantics, pragmatics) contribute to the interpretation of the pronoun and the right dislocation construction as a whole. The construction's conventionalized status makes it possible to use it locally in an incremental fashion by expanding a turn after a clear point of completion or by using prosodic projection at the end of the first clause to signal more upcoming talk.

Our study focuses on the ways in which the bi-clausal right dislocation construction is used to accomplish social actions. We will show that the first clause performs a backward-oriented action (such as accepting a proposal, assessing another participant's action, or asking a question which builds on the prior turn), while the second clause has a more forward-oriented function. By specifying or even shifting the reference of an argument of the verb of the first clause, a speaker can move on to a different topic, or focus on a different facet of a current topic. Thus, the analysis of the complement clause importantly focuses on semantic and referential practices.

Even though the right dislocation of complement clauses is not seen as belonging to Standard German in normative grammars, our data from spontaneous talk-in-interaction show that it is not rare at all, but is a routinely used, productive bi-clausal construction. We argue that the construction is well motivated by the 
contingencies of talk-in-interaction: It allows for an incremental specification of action and meaning over the course of its production. Reasons for specification may be a co-participant signaling a lack of understanding, the speaker's emergent online planning, the identification of ambiguities or vagueness via self-monitoring of ongoing turn production, or even rhetorical uses to shift the topic or to replace referents of predications. The construction offers a smooth, conventionalized way to expand a turn.

\section{Right dislocation in German}

\subsection{General properties of the construction [[NP V das $\left._{\mathrm{i}}\right]\left[\right.$ dass $\left.\mathrm{NP} \mathrm{VP}_{\mathrm{i}}\right]$}

The construction consists of two clauses: A main clause containing the neuter demonstrative pronoun $d a s^{2}$ (either subject or object of the verb) and a complement clause with the complementizer dass that is co-referential with the demonstrative. The first clause of the construction could in principle be used independently as it is syntactically and semantically complete; ${ }^{3}$ the pronoun das anaphorically refers to an antecedent in the ongoing verbal interaction (or to something inferable from it) ${ }^{4}$ or deictically to something that is not verbally expressed but present in the situation.

Clauses with demonstrative pronouns are very frequent in spoken German; ${ }^{5}$ the demonstrative is mostly not specified any further. If speakers want to specify the reference of das, however, they can make use of an expansion, which can take the form of a complement clause. If the dass-clause re-specifies rather than merely explicating the reference of das, this can lead to a reinterpretation of the matrix clause. The occurrence of a following complement clause that semantically fills an argument slot of the verb of the main clause, which was already occupied by

2. The articulation of the demonstrative varies according to regional dialect and other factors such as register (das, des, dis, dit, dat).

3. The matrix clause is always semantically complete in the sense that it contains a full proposition, that is, all obligatory semantic roles of the verb are realized. It may, however, not be sufficiently specified if the reference of the demonstrative is unclear or ambiguous.

4. In line with Consten and Schwarz-Friesel (2007), we use anaphoric not only for references to antecedents, that is, previously mentioned referents and propositions, but also to conceptual entities that have to be inferred (e.g., by metonymic relations) from anchors in prior talk ("indirect anaphora").

5. See e.g., Proske (2013) for the frequency and functions of copular clauses with das as a subject, which are one of the most frequent formats that are often expanded by complement clauses. 
the demonstrative, retrospectively turns the main clause into a matrix clause. The resulting construction is treated as a type of right dislocation in the literature. We briefly illustrate its structure with an example. Afterwards, we describe different prosodic realizations and discuss how they impinge on the projective properties of the first clause.

In (1), two friends are talking about a TV series. FR has just started watching the third season, while EG has already seen it when it was originally broadcast. FR tells EG that apparently there was one particularly spectacular episode in the third season, and that people even filmed their reactions to this episode and put them on YouTube (1. 1-6). EG reacts with a multi-unit turn containing several clauses with anaphora (1. 7-12), ${ }^{6}$ the last one of which is aber das hab ich nich MITbekommen ('But I wasn't aware of that.', 1. 14).

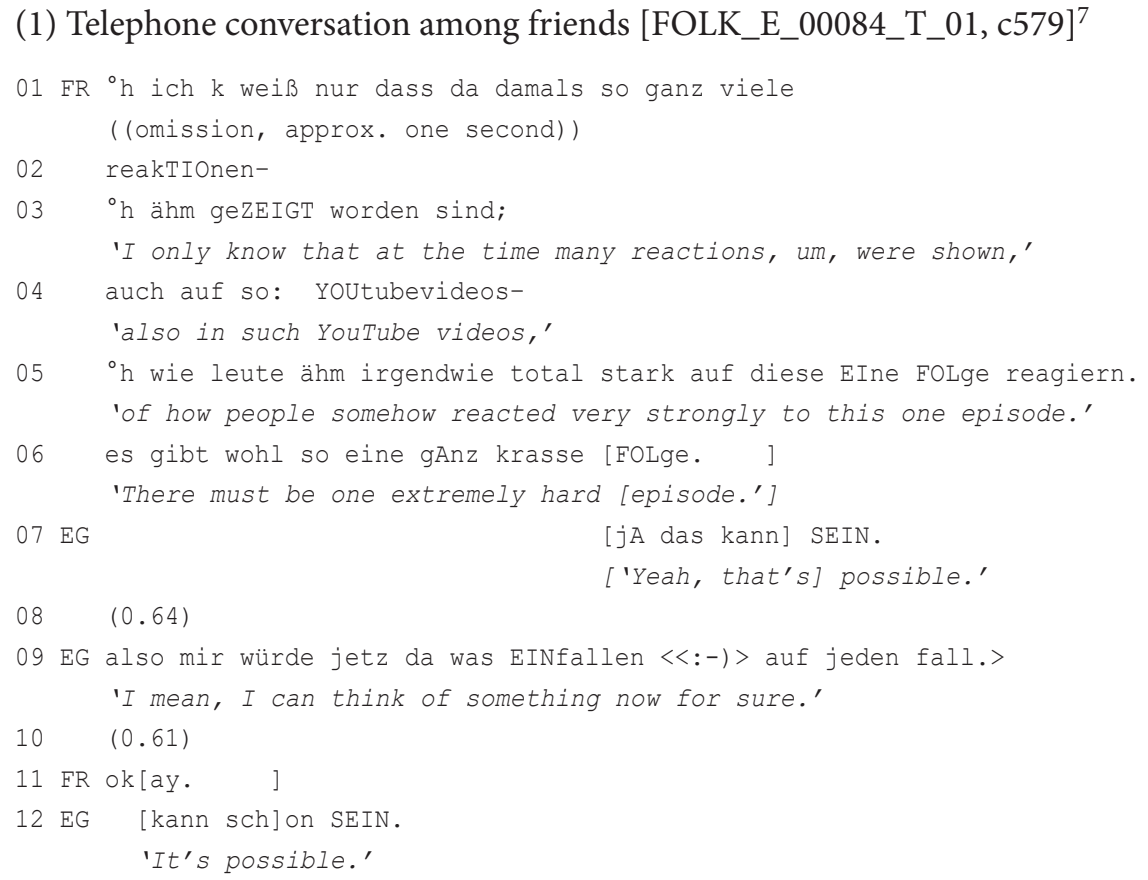

6. In a more detailed analysis that cannot be given here, these other anaphora help disambiguate the reference of das in line 14, as some of the predications are contradictory (einfallen vs. nicht mitbekommen).

7. The transcription of the examples follows the conventions of GAT 2, as outlined by Selting et al. (2009). Each line represents one intonation unit. There are five different terminal pitch contours: low falling (.), slightly falling (;), level (-), slightly rising (,), and high rising (?). Primary accents are marked by upper case of the whole accented syllable and secondary accents by upper case of the vowel of an accented syllable. 


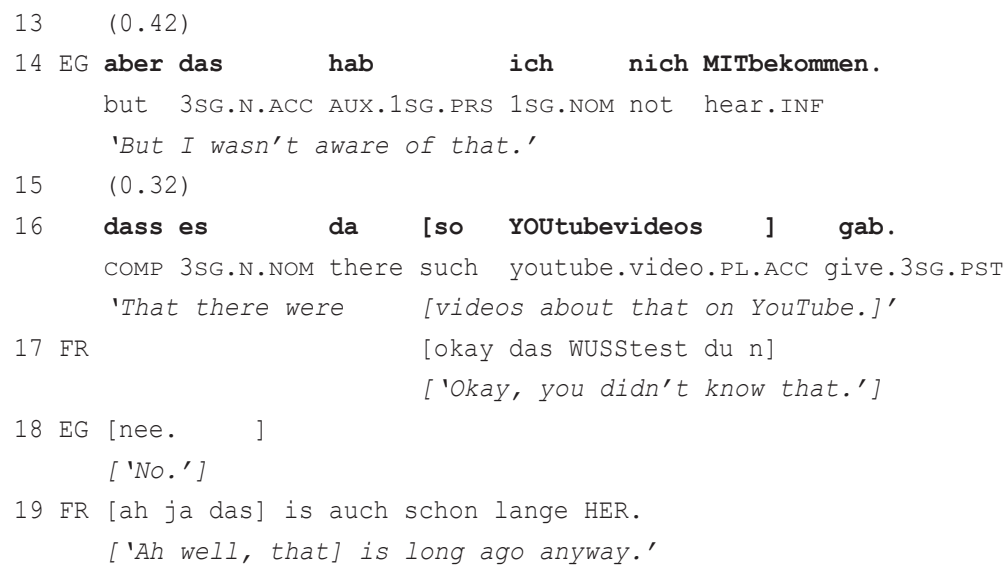

The pronoun das in line 14 can be interpreted as a "complex anaphor" (Consten, Knees, \& Schwarz-Friesel, 2007), which can refer to FR's prior turn as a whole or just to a part of it. Thus it could mean that EG was 'not aware' either of all of what FR has said in lines 1-6 or of only one of the facts she mentioned. FR's lack of uptake after the clause in line 14 is taken by EG to indicate that a specification (1. 16) is necessary. EG then adds a dass-complement clause, dass es da so YOUtubevideos gab. ('That there were videos about that on YouTube', 1. 16), which specifies the reference of das. It narrows down the issues that EG was not aware of to a subset of those mentioned in FR's turn. Only when EG has started to give the specification does FR display that she understands what EG is referring to (1. 17). While in this example the interactive motivation for specifying the pronominal reference by adding a complement clause seems to be transparent, in most cases in our collection we do not find that speakers add the complement clause because of (the lack of) listeners' responses. Yet, we find syntactic, semantic, pragmatic, and prosodic indicators that index the possible (in-)completeness of the preceding clause and thus project turn continuation.

Literature on the grammar of German (Altmann, 1981: 167ff.; Zifonun, Hoffmann, \& Strecker, 1997: 548) claims that the matrix clause of the right dislocation construction is always prosodically independent, separated by a pause, and concluded with a falling final intonation contour as in Excerpt (1). Yet, our data show that the complement clause and the matrix clause are almost as often produced together in the same intonation unit as they are produced as separate 
intonation units. If the matrix clause constitutes an intonation unit of its own, it can be produced with a falling, level, or rising contour. ${ }^{8}$

We consider cases such as (1), in which the first clause is complete on all levels of linguistic description (syntax, semantics, pragmatics, and prosody) and therefore ends in a "complex TRP" (Ford \& Thompson, 1996), to be clear cases of expansion (or: turn continuation, see Auer 1996; Couper-Kuhlen \& Ono, 2007; Ono \& Thompson, 2012). ${ }^{9}$ In contrast, cases in which the first clause is not complete on all levels are treated here as projecting (on at least one level, cf. Auer, 2005, 2010), that is, the first clause makes expectable a continuation, although not necessarily one by a complement clause. Thus, projection can result from syntactic, semantic, pragmatic, or prosodic incompleteness. As the construction under scrutiny contains a syntactically and semantically complete first clause in most cases, ${ }^{10}$ it is prosody and pragmatics that can be seen as decisive regarding projection here. If the first clause does not end in a point of prosodic completion, this still does not mean that the form of the continuation is pre-defined in any way (the continuation may, for example, also take the form of a simple main clause). The prosodically projecting cases can be split into two groups: a) the two clauses are produced in one intonation unit (mostly with two focal accents, one per clause) (see Excerpt (2)), or b) each clause is produced as a separate intonation unit and the first one ends in a non-final (rising or, more rarely, level) contour (see Excerpt (3)). ${ }^{11}$ In the expansion cases, the first clause ends with a final, falling or high rising, intonation contour and the complement clause is added as a separate intonation unit (see Excerpt (1)).

8. 56 of the 93 cases $(60 \%)$ are produced in two separate intonation units. Of these, 28 have a falling final contour on the first clause, 19 a rising one (only five of which are high rising), and 8 a level one. 37 of the 93 cases (40\%) are produced within one intonation unit; 29 of these intonation units feature two focal accents; 8 have only one focal accent. In one case, the intonation unit is cut off after the complementizer.

9. This roughly corresponds to what Schegloff (1996) has called increment, a term that we avoid because of certain ambiguities associated with it (see Deppermann \& Proske, 2015 for a discussion).

10. In some cases, the first clause cannot be regarded as semantically complete, as there is no antecedent or anchor for the demonstrative. In these cases, it functions as a non-referential expletive as es in the extraposition construction does. This lack of referential specification can be regarded as semantic incompleteness.

11. We use the term intonation unit as it is understood in interactional studies on spoken English and German, that is, as "a stretch of speech uttered under a single coherent intonation contour" (Du Bois et al., 1993: 47). An intonation unit has at least one focal accent and a terminal pitch contour following it; among the optional 'boundary cues' are features such as audible in-breath, pause, change in pitch, and change in tempo (see e.g., Chafe, 1994; Selting et al., 2009). 
(2) Board game [FOLK_E_00010_T_01, c468]

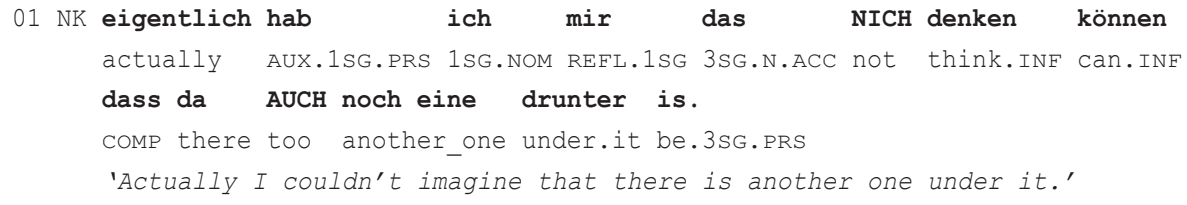

(3) Mediation meeting (Stuttgart 21) [FOLK_E_00064_T_06, c70]

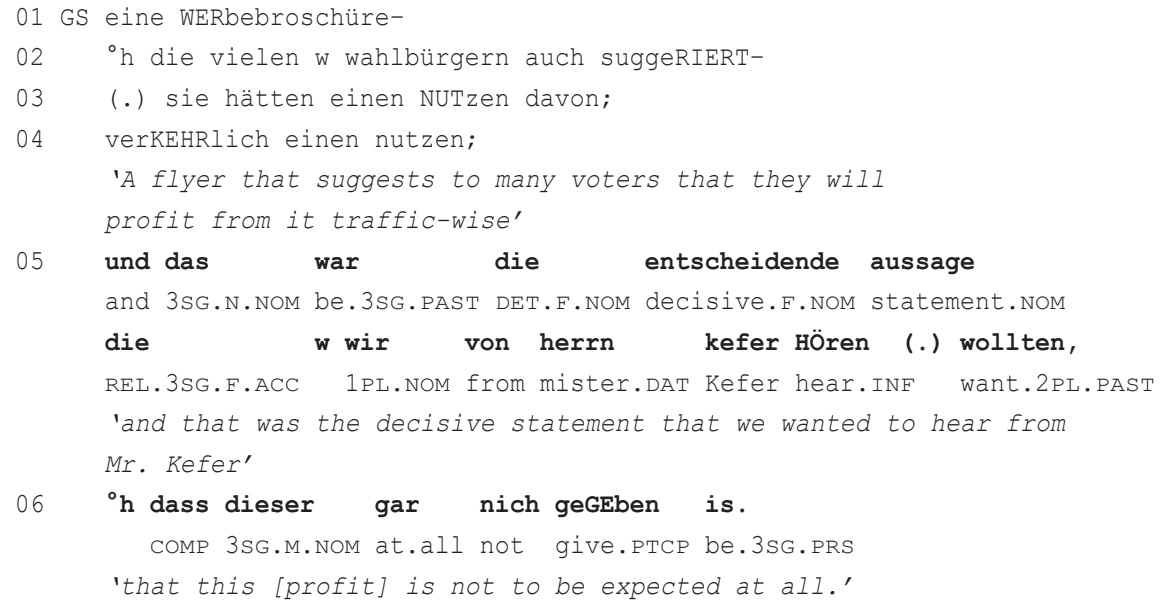

Pragmatic projection comes into play in addition to prosodic projection. It may be the case that prosody signals completion in line with syntax and semantics, but pragmatically the turn cannot be regarded as complete (see Excerpt (4) below).

\subsection{Right dislocation in the literature}

The right dislocation construction is usually defined as consisting of a clause containing a pro-form and a phrase realized after ('to the right of') the clause that is coreferential with the pro-form (see e.g., Altmann, 1981: 54f.; Averintseva-Klisch, 2009: 3). The use of the term right dislocation (in German: Rechtsversetzung) was originally restricted to clause-final phrases with a nominal core, that is, NPs and PPs (e.g., ${ }^{\circ} h$ also die fand ich sehr SCHWER, diese PROsabände- 'well, I found them very hard [to understand], these prose volumes' FOLK_E_00059_ T_01, c742). ${ }^{12}$ The interactional functions of the construction, most prominently repair,

12. The term was coined by Ross (1967). In the generative framework, the complement clause is seen as 'right-dislocated' from its original position within the matrix clause, which is occupied by the expletive pronoun instead. Although this transformational view of the constructions does not adequately capture their emergence in spoken language, we use the term because it 
have been described for German in studies on various types of phrasal expansions of clauses (e.g., Auer, 1991, 1996, 2007; Uhmann, 1993). ${ }^{13}$ The possibility of dislocating complement clauses to the right is only rarely considered (see e.g., Altmann, 1981: 167ff.; Zifonun, Hoffmann, \& Strecker 1997: 1475f. for short mentions). There are no major studies on the construction in German, neither from a theoretical syntactic nor from a usage-based or interactional point of view. ${ }^{14}$ The construction has two formal relatives that are considered standard in German: ${ }^{15}$ a) a matrix clause with one argument realized as a complement clause, and b) a matrix clause within which one argument is realized as an expletive pronoun ( $e s^{\text {' }} \mathrm{it}$ ') before the same argument is realized again as a complement clause ('extraposition'). ${ }^{16}$ All three constructions are restricted to matrix clauses with complement-taking predicates, that is, verbs that take a propositional argument that can be realized either as a complement clause or a neuter pronoun (es or das). This is also why right-dislocated clauses have much less in common with right-dislocated NPs and PPs than with the above-mentioned bi-clausal structures: Right dislocation of phrases can occur with any verb.

Because of their close structural similarities, literature on matrix clause constructions and the extraposition construction is potentially relevant for describing the functions of the right dislocation construction. Matrix clauses in German and English have been investigated for their framing functions: complement-taking verbs often have epistemic, evidential, or evaluative semantics. The framing function and the projection of upcoming talk has also been the focus of studies on extraposition. Although the matrix clause is formally complete (in contrast to a

is common in non-transformational approaches (e.g., Altmann, 1981: 54) and in interactional linguistics (e.g., Pekarek Dohler, De Stefani, \& Horlacher, 2015) as well.

13. See also Horlacher (2015) and Pekarek Doehler et al. (2015) for right-dislocated NPs in spoken French. These authors emphasize that-apart from the function of referential repair, which the literature on right dislocation in many languages has focused on (see e.g., Geluykens, 1987) - phrasal right dislocation has several functions concerning turn-taking and turn construction, such as dealing with issues of recipiency, as was also found in our example of clausal right dislocation in Excerpt (1).

14. But see Keevallik's (2011) investigation of clause combinations with projecting pro-forms in spoken Estonian.

15. Es is held to be the default expletive pronoun (Gallmann 2009: 822f., 1055), while das is regarded as a non-standard expletive.

16. If our Excerpt (1) would have been realized as a simple matrix clause construction or as an extraposition construction, it would look as follows: Aber ich hab (es) nicht mitbekommen, dass es da so Youtube-Videos gab. The propositional meaning is the same as that of the right-dislocated case. 
matrix clause without an expletive) and makes an epistemic, evidential, or evaluative statement, it is semantically incomplete because one argument of the verb has been only formally realized; it projects a propositional referent for which the pre-posed assertion holds (Couper-Kuhlen \& Thompson, 2006, 2008; Günthner, 2009) ${ }^{17}$ This relationship can also be found for cases of right dislocation in which the first clause is prosodically projecting but the demonstrative pronoun is nonreferential or cannot be interpreted unambiguously.

\section{Data}

Our data come from the 'research and teaching corpus of spoken German' (FOLK; see Schmidt, 2014), a growing reference corpus of German talk-in-interaction. The corpus comprised 133 hours of spoken interactions when we set up our datacollection. ${ }^{18}$ It contains a broad variety of private, institutional, and public interaction types (e.g., dinner table conversations, private telephone conversations, work meetings, classroom interaction, university vivas, panel discussions) with speakers of German as a first language. We selected 13 interactions (27 hours), for which all occurrences of dass were inspected manually. ${ }^{19}$ We found 93 cases of rightdislocated dass-complement clauses (this means that the construction occurs approximately every 17 minutes). These 93 cases were analyzed sequentially and for several formal and functional features.

17. Because of the broad functional range of das, the right dislocation of complement clauses seems to be much more common in German than in English. The English extraposition construction fulfills more functions because it is used anaphorically more often than German es (cf. Couper-Kuhlen \& Thompson, 2006, 2008, who do not use the term 'anaphoric', but describe the it in the first clause of the English extraposition construction as often both 'forward-' and 'backward-oriented'). The close relation between extraposition and right dislocation in German has not been discussed in detail in the literature. Moreover, it has not yet been investigated empirically whether it is not es-as claimed in grammars-but das that is the default pronoun 'replacing' complement clauses realized 'to the right' of a matrix clause, at least in spoken German.

18. We built the collection in May 2015. The corpus is available at http://dgd.ids-mannheim.de. All excerpts can be retrieved by the interaction and contribution numbers in the header above each excerpt.

19. The corpus contains more than 8,000 occurrences of dass-clauses, which can be retrieved automatically. For our analysis, we selected interactions from different interaction types, in order to cover a wide range of usages of the construction. 


\section{Uses of the right dislocation construction}

The functions of the right dislocation construction ${ }^{20}$ do not differ systematically depending on the sequential or turn-internal position in which it is used. Rather, its basic characteristics (bi-partite structure, (potentially) anaphoric demonstrative that is (potentially) co-referential with a complement clause) bear different weight in different contexts of use. First, we look at (mostly) turn-initial uses, by which a speaker takes up (parts of) a prior speaker's turn with the demonstrative. In these cases, the complement clause specifies a propositional referent that was introduced by another speaker. Second, we deal with turn-internal uses, by which a speaker ties together parts of their own multi-unit turn, ${ }^{21}$ that is, the complement clause specifies a propositional referent that the speaker has introduced themselves. Third, we analyze co-constructed cases-other-initiated expansions and collaborative constructions. In these cases, the reference of the demonstrative is observably negotiated by the co-participants.

\subsection{Co-reference with (parts of) a prior turn}

The first clause of a right dislocation construction with which a speaker takes up (parts of) another speaker's turn occurs close to the beginning of the turn in most cases. Mostly, it is turn-initial or the first clause in a turn, occurring, for example, after a turn-initial particle. ${ }^{22}$ In the majority of these cases, das refers to a nonadjacent TCU in the prior speaker's turn. Reference to the immediately preceding TCU of the prior speaker's turn also occurs. ${ }^{23}$ Ambiguity of the antecedent which is referred to by das in the first clause, or inability to resolve its reference because of the distance of the antecedent, can thus be only one reason why referential (re-) specifications by complement clauses occur.

The following examples show that what later becomes interpretable as the matrix clause of a right-dislocated complement clause typically implements an action that is backward-oriented (i.e., operates on prior talk), such as asking a question about the current discourse topic or accepting a proposal. As the pronoun das

20. We refer to the bi-clausal right dislocation construction in an abbreviated way as the 'right dislocation construction?

21. In 37 of the 93 cases the demonstrative is co-referential with (parts of) a prior turn of another speaker; in 35 it is co-referential with a prior part of the same speaker's turn; in 21 it is non-referential or cataphoric.

22. 26 of the 37 cases referring to another's turn occur close to the turn beginning.

23. 15 of the 37 cases referring to another's turn refer to an immediately preceding TCU. 
refers to something that is treated as given, the verb of the clause (and potentially additional lexical arguments) gains prominence as new information. Mostly, the matrix clause is short. The complement clause contains a (re-)specification of the referent that was already indexed as given.

Excerpt (4) comes from a lesson at a professional school. The teacher (GS) is talking about the possibility of employees getting support from their boss when taking part in a training course (1. 1-13).

(4) Lesson at a professional school [FOLK_E_00004_T_02, c463]

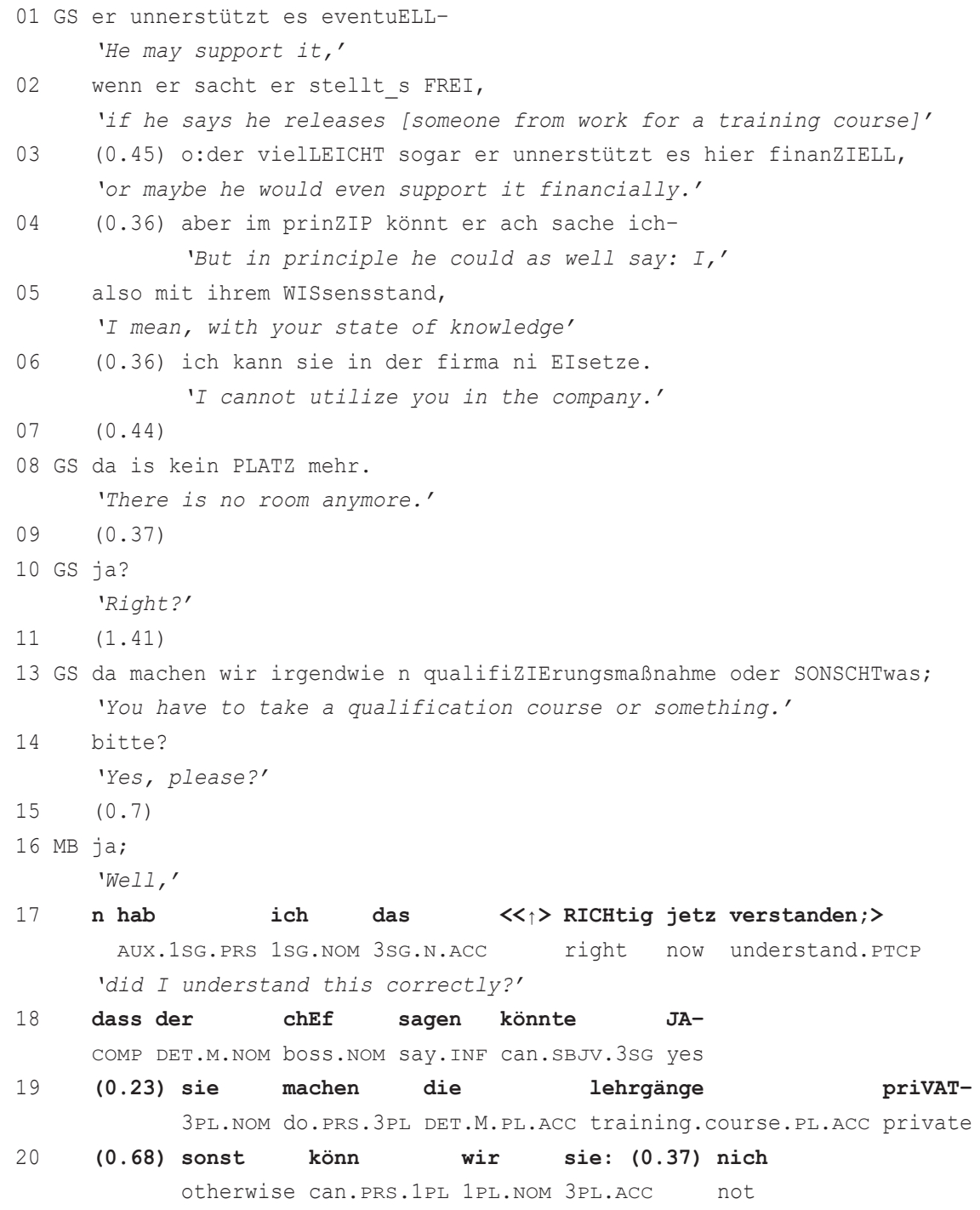




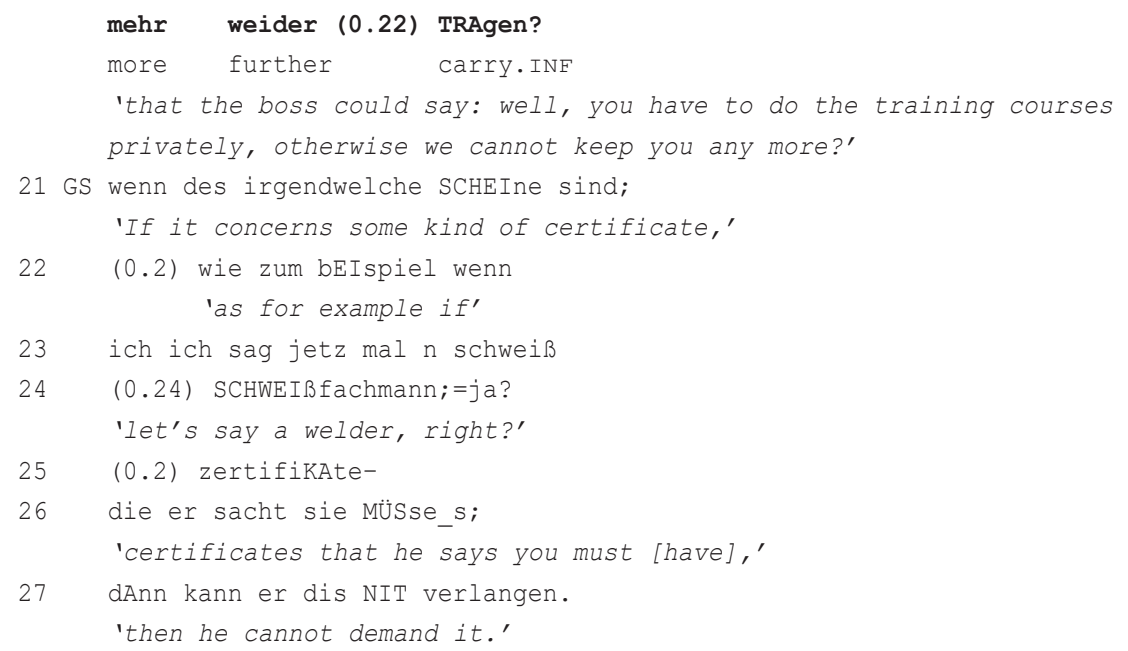

MB starts asking a question in line 17: hab ich das RICHtig jetz verstanden; 'Did I understand this correctly?'. This clause ends in a possible syntactic and prosodic point of completion and can be regarded as semantically complete if das is taken to refer to GS's prior turn as a whole. Moreover, as a question, the clause performs a sequentially first action that creates conditional relevance. However, it does not end in a pragmatic point of completion, as GS cannot answer the question of whether $\mathrm{MB}$ has understood her correctly unless $\mathrm{MB}$ offers a candidate understanding, because GS does not have access to his mental state. Thus, it is only after MB has explicated his understanding of GS's turn with the complement clause in lines 18-20 that GS provides an answer (1. 21-27). Whereas in Excerpt (4), the necessity for specifying what das refers to depends on the semantics of the matrix clause verb, there are other cases, in which it arises from contextual factors, such as several possible antecedents, as in Excerpt (1) above. Specification is more important for questions than for other actions, for example responsive epistemic statements as in (1), as they make relevant a next action by the recipient. In any case, the right dislocation construction offers a way of 'chunking' a turn, that is, of first performing the main action such as asking a question and then specifying reference. ${ }^{24}$

Excerpt (5) comes from the same telephone conversation as (1), among two students. They are talking about their work for a newspaper. FR has committed to writing an article, but has not done so yet; EG proposes that FR should write an e-mail to the chief editor explaining that she will still write the article (1. 1-4), so that he won't assign the topic to anyone else (1. 5-6).

24. Each clause can be seen as a chunk, thus the backward-oriented action (matrix clause) and the specification (complement clause) are examples of grammatical and pragmatic "packaging" (Chafe, 1976). 
(5) Telephone conversation among friends [FOLK_E_00084_T_02, c92]

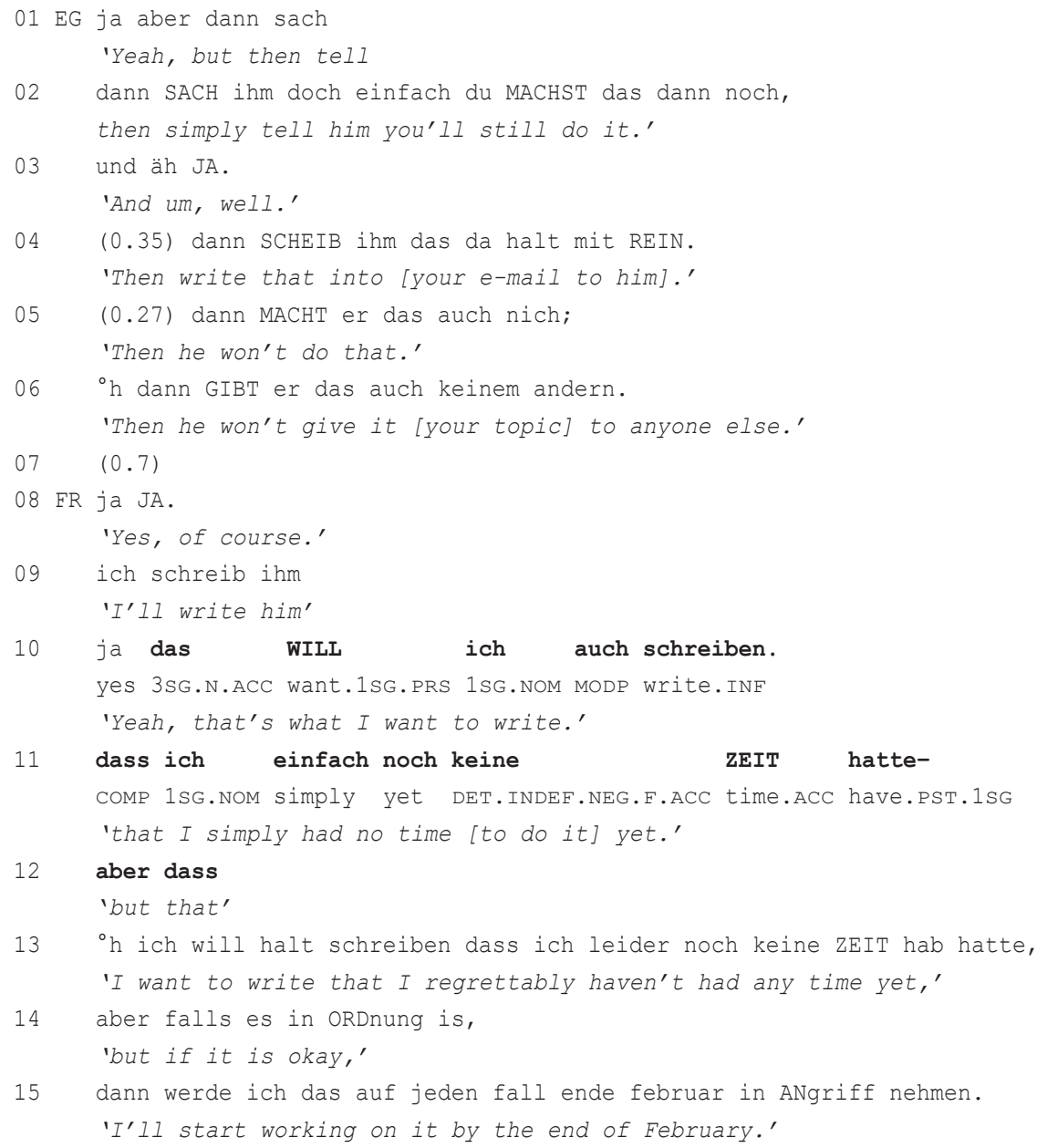

FR starts her response with a response token (ja JA., 1. 8, and again ja in 1. 10) (Barth-Weingarten, 2011; Golato \& Fagyal, 2008) and accepts EG’s proposal with the clause das WILL ich auch schreiben. ('Yeah, that's what I want to write', 1. 10). The pronoun das refers to a non-adjacent part of EG's turn in line 2 ( $d u$ MACHST das dann noch, 'you will still do it'). FR demonstrates epistemic autonomy as she identifies the proposal as her own prior intention by using the modal verb wollen 'want. The clause is complete syntactically, semantically, and pragmatically and ends with a falling intonation contour. After this possible point of completion, FR adds a complement clause that mentions a reason for not having written the article (keine ZEIT hatte 'had no time', 1. 11). This does not clarify the prior reference of das, but retrospectively shifts it to something only metonymically related to what 
was actually said by EG. While the matrix clause signals compliance, the specification in the complement clause changes the kind of action that FR commits herself to. FR then uses the complement clause construction for a turn expansion which gives a more detailed explication of her prior intention: She contrastively adds a further complementizer (aber dass 'but that', 1. 12), but then abandons the structure. The reformulation in lines 13-15 shows that the reason she gave before is only one part of the further specification of what she intends to write.

The "janus-faced", both retrospective and prospective, orientation of the demonstrative imbues the construction with a rhetorical potential that becomes clear in cases such as Excerpt (5): The anaphoric pronoun establishes a cohesive tie with the prior speaker's perspective; the TCU signals affiliation. This is then transformed into the announcement of an action which can be more or less at odds with the prior speaker's proposal. Still, the shift is not marked in any way, but the right dislocation makes it appear to be a reformulation.

Excerpt (6) shows how the construction is used for referring to prior actions of others when there is no verbal antecedent to the pronoun das. A group of men is playing a "football manager" game, in which they bid on players to build a virtual team. We join the action when they are bidding on the player Cacau.

(6) "Football manager" game [FOLK_E_00021_T_11, c39]

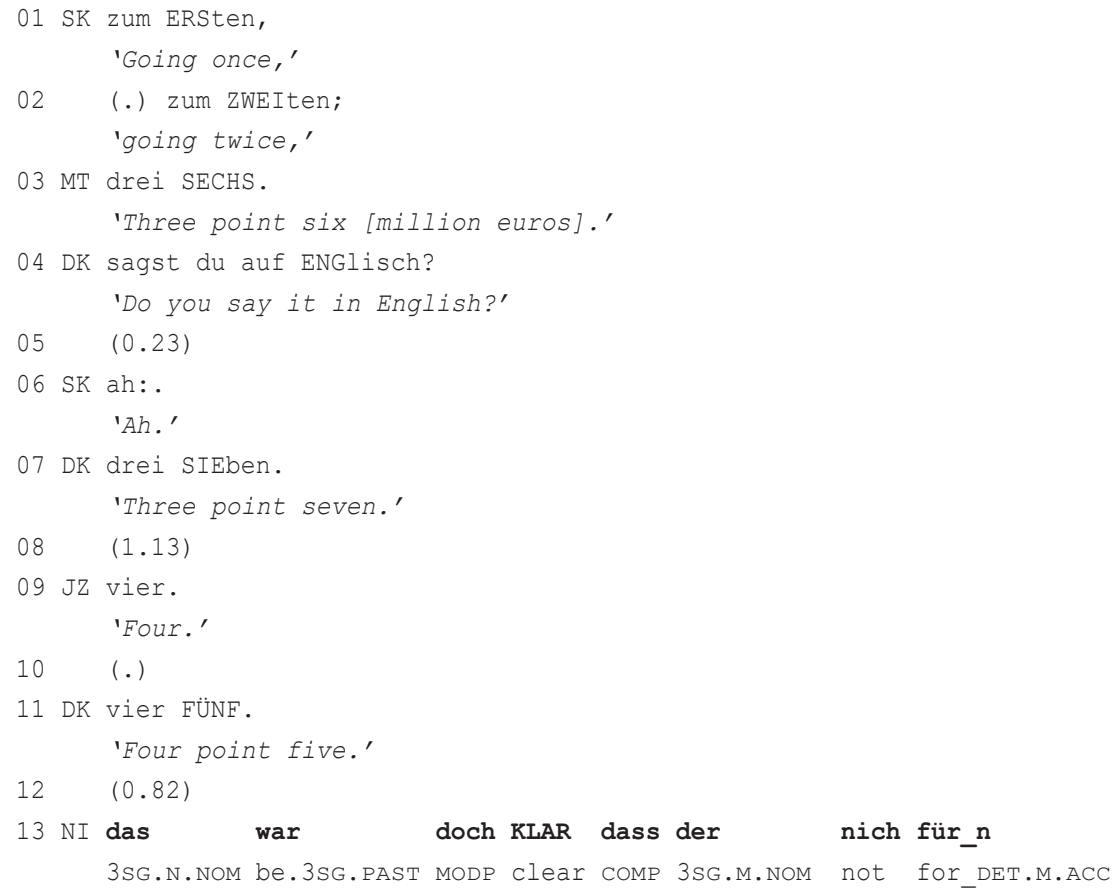




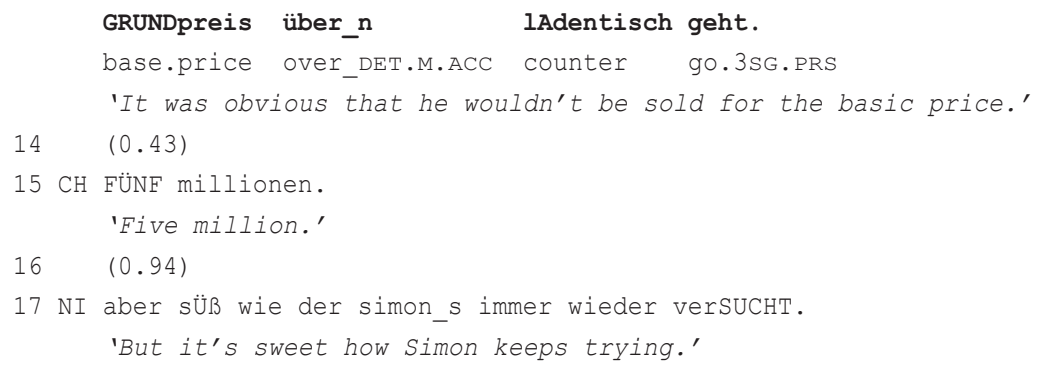

SK is trying to end the bidding sequence (1. 1-2), but the others keep going. In line 13, NI comments on this using the right dislocation construction: The matrix clause expresses an epistemic stance towards the ongoing interaction and evaluates it as expectable (das war doch KLAR 'that/it was obvious'). The complement clause, which is realized as a continuation of the same intonation contour, summarizes the bidding activities (nich für_n GRUNDpreis über_n lAdentisch geht 'not be sold for the basic/starting price'). At the same time, it specifies the reference of das in the matrix clause, which otherwise could not be unambiguously interpreted. By the time das is uttered, it could be interpreted as referring to the immediately prior turn by DK (vier FÜNF. 'four point five', 1. 11), or to the whole prior bidding sequence, or even to something in the non-verbal context. Thus, the interpretation of the pronoun as not anaphoric but as discourse-deictic ${ }^{25}$ and at the same time cataphoric ${ }^{26}$ is only possible because of the complement clause.

As the examples show, the construction can emerge in the course of constructing a turn online, as in (4) and (5). It can also be used as a whole, as in (6), where the cohesive prosodic contour and the need to specify the reference of das make it likely that it was produced (and perceived) as an integrated unit from the start. In either case it links two potentially separate actions through a cohesive grammatical construction. Das thus creates a retrospective link, while at the same time affording the potential for further (re-)specification. The right dislocation construction thus allows for an incremental constitution of meaning and reference. Pragmatically, this can be used to reconcile the simultaneous display of affiliation and implicit disagreement.

25. Both das and the complement clause refer meta-pragmatically to prior actions and not to a proposition from prior discourse, as in the earlier excerpts.

26. There are 21 cases in the collection that are cataphoric or non-referential. It is not always easy to determine whether the speaker has intended retrospective, (discourse-)deictic reference or whether the pronoun is only cataphoric, that is, prospective. These cases show no special formal characteristics; their prosodic delivery, for example, varies just as much as it does in the other cases. 
4.2 Co-reference with prior parts of the same turn

We now turn to cases in which the demonstrative in the matrix clause refers to an adjacent or non-adjacent prior TCU in the same turn. ${ }^{27}$

The first example comes from a public mediation session for the railway construction project "Stuttgart 21". In Excerpt (7), an expert presents the speed profile of the planned new trajectory over several TCUs (1. 1-13). He then assesses these facts positively: des is meine damen und herren ein sehr großer VORteil, ('This is, ladies and gentlemen, a huge advantage.', 1. 14). This assessment explicitly turns the facts, which were presented in a rather neutral fashion, into arguments in favor of the new trajectory.

(7) Mediation meeting (Stuttgart 21) [FOLK_E_00064_T_01, c619]

$01 \mathrm{VK}{ }^{\circ} \mathrm{h}$ wenn wir uns jetzt mal die schnEllfahrstrecke

Anschauen mit dem geSCHWINdigkeitsprofil;

'Now, if we take a look at the speed profile of the

high-speed railway line'

02 (0.41) und äh kucken woher KOMMT denn eigentlich der fAhrzeitgewinn? 'and, um, try to find out where the gain in time comes from,'

$04{ }^{\circ} \mathrm{h}$ dass wir (0.67) bei der ScHNELLfahrstrecke,

05 (.) hier,

06 (0.43) im hauptbahnhof STUTTgart,

$07 \quad(0.36)$ heRAUSbeschleunigen?

'that the train on the high-speed line speeds up when

leaving Stuttgart main station,'

$08(0.34)^{\circ} \mathrm{h}$ dann eine geschwindigkeit von

zweihundertFüNFzig kilometer pro stunde erREIchen,

'then gains a speed of $250 \mathrm{~km} / \mathrm{h}$.'

(.) und diese geschWINdigkeit,

'and this speed,'

$10{ }^{\circ} \mathrm{h}$ bis auf einen leichten einbruch in dem beREICH,

'apart from a slight setback in this area,'

$11{ }^{\circ} \mathrm{h}$ praktisch HALten können,

'can practically be sustained,'

12 bevor wir dann bei ULM,

13 (.) wieder mit der geschwindigkeit hiNUNtergehen.

'until we lower the speed again when we reach Ulm.'

$14{ }^{\circ} \mathrm{h}$ des is meine damen und herren ein

3SG.N.NOM be.3SG.PRS POSS.PL lady.PL and gentleman.PL DET.INDEF.M.NOM

27. In 18 of these 35 cases das refers to a non-adjacent prior TCU, in 17 cases to an adjacent one. 


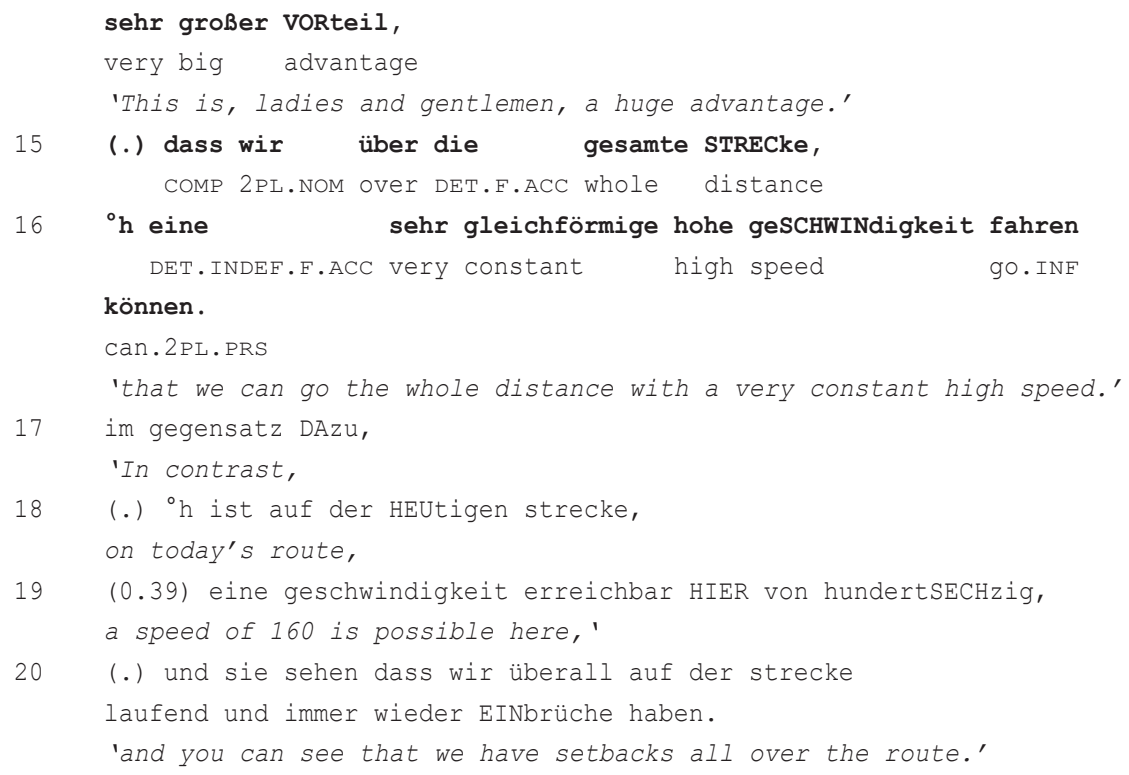

The assessment des is meine damen und herren ein sehr großer VORteil, ('This is, ladies and gentlemen, a huge advantage., 1. 14) is syntactically and semantically complete. The final contour of the intonation unit, however, projects turn continuation. The added complement clause, dass wir über die gesamte STRECke, ${ }^{\circ} h$ eine sehr gleichförmige hohe geSCHWINdigkeit fahren können. ('that we can go the whole distance with a very constant high speed., 1. 15-16), disambiguates the reference by making clear that it includes all of the speaker's talk on the issue and not just a part of it. The complement clause offers a concise summary of it. This serves as an anchoring point for the following topic expansion, which contrasts the planned trajectory with the speed restrictions of the current one (1. 17-20). The right dislocation construction here is a means to coherently relate stance-taking or assessments to summaries or repetitions of the main argument made before. This turn-structuring use is found in interaction types with argumentative multi-unit turns, such as classroom interaction, university vivas, and meetings.

In contrast to such projecting cases, which often seem to be used purposefully, cases of expansion show how the right dislocation construction emerges out of the contingencies of online planning and turn-taking. Excerpt (8) comes from a lesson at a professional school on the topic 'goals of apprenticeship'. Close to the end of the lesson, the teacher (GS) wraps up the topic 'skills'. 
(8) Lesson at a professional school [FOLK_E_00004_T_02, c1217]

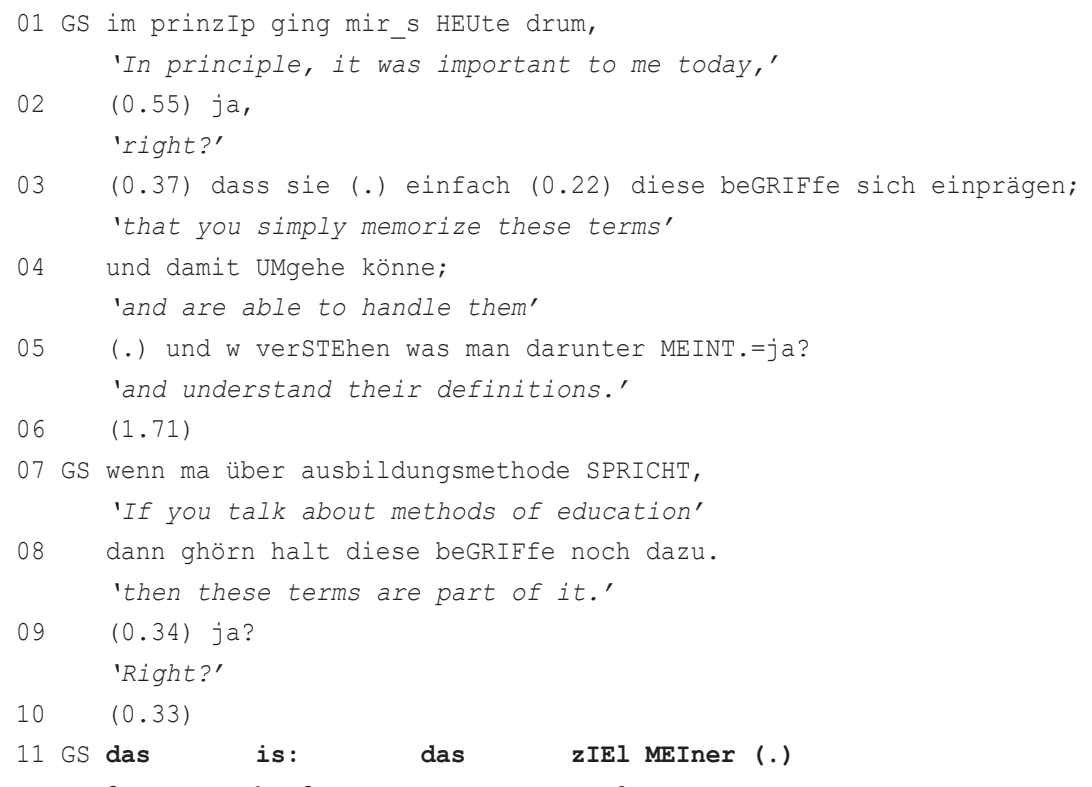

3SG.N.NOM be.3SG.PRS DET.N.NOM goal DET.POSS.F.GEN

Unterrichtsstunde heut. $=$ ne?

lesson today PRTC

'That's the goal of my lesson today, right?'

12 (1.07)

13 GS dass sie wissen sie MüSsen (.)

COMP 3PL.NOM know.3PL.PRS 3PL.NOM must.3PL.PRS

dem (0.25)azubi kompetenze vermittle;

DET.M.DAT apprentice.DAT skills.ACC teach.INF

'that you know you have to teach an apprentice certain skills'

$14(0.37)$

15 GS un was damit geMEINT is.

and 3SG.INT there with mean.PTCP AUX.PASS.3SG.PRS

'and what is meant by that.'

$16(2.25)$

17 GS vor dem begriff kompetEnze hatte ma scho_ma_n beGRIFF, 'Before the term 'skills' we had talked about another term,

$18(0.33)$ ne?

right?'

$19(0.63)$

20 GS dis ÄNdert sich so ab und zu ma,

'- That changes from time to time. -'

21 (2.84) der nannte sich SCHLÜSselqualifikatione.

'That one was called key qualifications.' 
GS explains that the aim of the last exercise was to familiarize the participants with certain technical terms (1. 1-9). She refers back to what she has said before with das and classifies it as das zIEl MEIner (.) Unterrichtsstunde heut. ('the goal of my lesson today., l. 11), creating a TRP, which is emphasized by the question tag $n e$ ? ('right?', l. 11). After a pause (1. 12), GS uses an expansion with a complement clause (1. 13-15) to re-phrase her goals. She offers a concrete example (kompeTENze 'skills', 1. 13) for the aforementioned abstract term beGRIFfe ('terms' or 'concepts', 1.3 and 8). ${ }^{28}$ This is used as a link (1. 17) to a next closely related topic SCHLÜSselqualifikatione 'key qualifications', 1. 21).

Just as when responding to a prior turn, in turn-internal use the right dislocation construction serves as a conventionalized format for tying a backward-oriented action and a specification or shift of reference together in one grammatical construction-either pre-planned by the speaker or emergently. In contrast to the uses referring to (parts of) another speaker's prior turn, the cases referring to parts of a speaker's own turn less often involve a shift to more remote referents. Rather, the construction is used for repetitions or specifications with only a slight shift in reference (as in (8)).

\subsection{Co-constructed uses: Referential self-repair and understanding-check}

Co-constructed uses of the right dislocation construction are rare in our data. Yet, they give particularly strong evidence for its conventionalized status. We will look at one example in which both parts of the construction are produced by the same speaker and the complement clause is a referential self-repair triggered by another speaker's repair initiation, and another example in which the matrix clause is produced by one speaker and the complement clause by another speaker as an understanding-check.

Excerpt (9) comes from a meeting at a social institution. A group of social workers discuss the activities of a boy who is cared for at their institution. SZ argues that it is important that the boy keeps attending his hapkido lessons, because the trainer accepts him as he is, integrates him well, and does not put pressure on him, as she suspects might be the case at other sports clubs (1.1-13).

(9) Meeting at a social institution [FOLK_E_00022_T_03, c1172]

01 Sz und deswegen find ich_s wIchtig ähm dass er dA echt daBEIbleibt;

'And that's why I think it's important that he keeps going there.'

28. Kompetenzen ('skills') have been mentioned earlier, in a previous lesson at the professional school. It is itself a cover term for several specific skills (e.g., Methodenkompetenz 'method skill') that were discussed in an earlier exercise in the current lesson. 
02 (.) weil dis halt auch noch ne gruppe isch wo geNAU, 'Because this is a group where

03 (0.82) wo der finn aber (0.24) mit gutem gewissen (.) so wie er Isch hingehen KANN. where Finn can go as he is without concern.'

$04 \quad(0.72)$

05 SZ weil da net wie in nem üblichen SPORTverein oder so so_n ähm'Because unlike in a normal sports club or something there's no $06 \quad(0.22)$

07 AW LEIStungsdruck. 'Pressure.'

08 sz mobbing oder leischtungsdrutsch äh druck STATTfindet. 'mobbing or pressure there.'

$09 \quad(0.95)$

10 Sz und w[eil] äh weil_s auch_n trainer isch der die die kinder gAnz andersch irgendwie äh im BLICK hat;

'And because there's a trainer who monitors the children well

11 HM [ja. ]

'Yeah.'

$12 \mathrm{Sz}$ und Ihn auch (0.57) auf sEIne art also so mit EINbezieht un so; and who integrates him in his own way.'

13 un dis gibt_s woandersch (0.35) [halt eher] (.) oder_s gibt_s halt sELten.

'And that's a rare thing elsewhere.'

$14 \mathrm{HM}$

[hm_m. ]

$15 \mathrm{SZ}^{\circ} \mathrm{h}$

$16 \mathrm{HM}[\mathrm{hm}:$.

$17 \mathrm{AW}$ [hast du] ihm dis bei

AUX.2SG.PRS 2SG.NOM 3SG.M.DAT 3SG.N.ACC at

eurem gespräch so geSAGT?

POSS.2PL.DAT conversation this_way say.PTCP

'Did you tell him that in your conversation?'

$18 \quad(0.2)$

19 SZ WAS denn?

'[Tell him] what?'

$20 \quad(1.6)$

21 AW ähm,

$22(0.28)$ dass er da so ANgenommen

COMP 3SG.M.NOM there as take.PTCP

wird

wie er

IS?

AUX.PASS.3SG.PRS as 3SG.M.NOM be.3SG.PRS

'Um, that he is accepted the way he is there.'

$23(0.73)$

$24 \mathrm{AW}^{\circ} \mathrm{h}$ äh [ich hab jetzt ]

'Um, now I' 


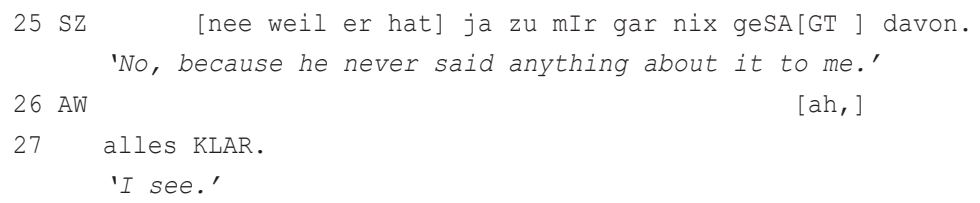

The reference of the demonstrative in AW's question hast du ihm dis bei eurem gespräch so geSAGT? ('Did you tell him that in your conversation?', 1. 17) can be interpreted as wide, encompassing SZ's whole prior turn. But it can also be interpreted as referring to only a part of it, for example the immediately adjacent TCU in line 13. Accordingly, SZ initiates a referential repair by asking WAS denn? ('TTell him] what?', l. 19). For her repair, AW uses the structural latency (Auer, 2015) of the syntax of her own prior turn and expands it with a complement clause. Thus, the non-projected expansion disambiguates the reference of the demonstrative. It is a formulation of SZ's TCU in line 3, but it also gives a concise summary of SZ's whole turn in lines 2-12; yet, it excludes the possibility that the question refers to the TCU in line 13.

In contrast to this other-initiated expansion, in Excerpt (10) a second speaker expands the first speaker's turn with a complement clause to check whether she has correctly recovered what the first speaker referred to. The example comes from the same telephone conversation as extracts (1) and (5).

(10) Telephone conversation among friends [FOLK_E_00084_T_02, c120]

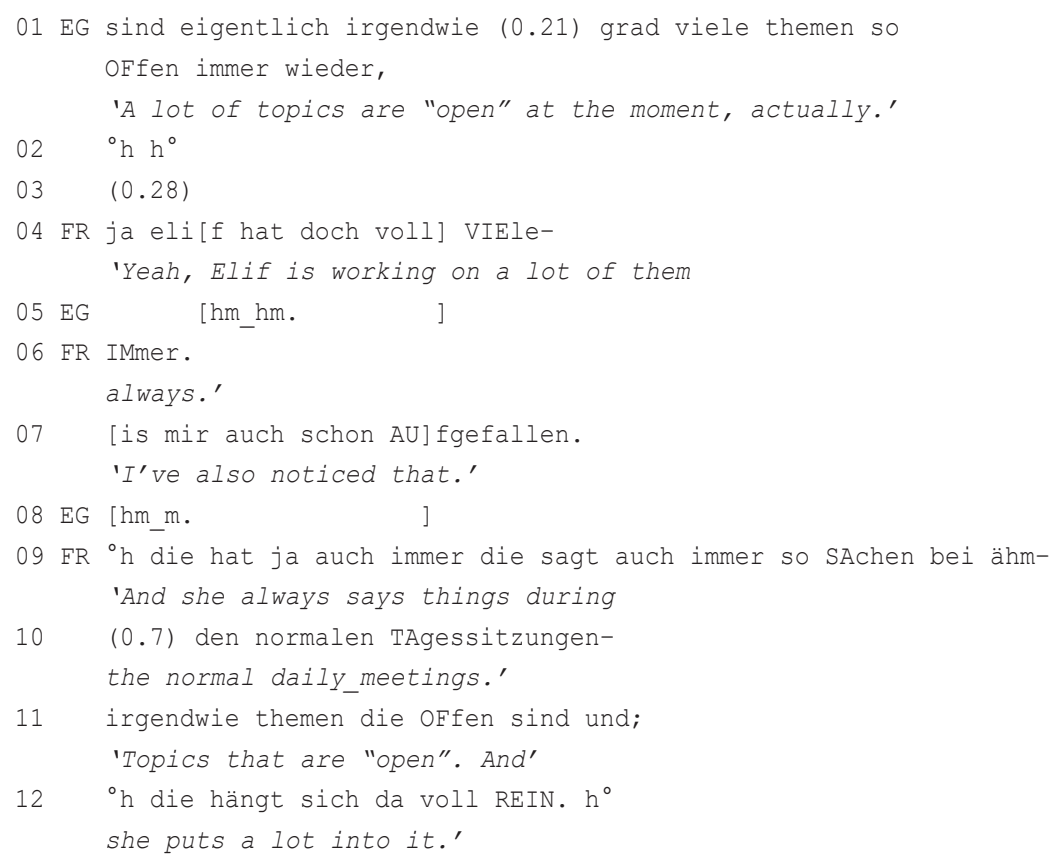




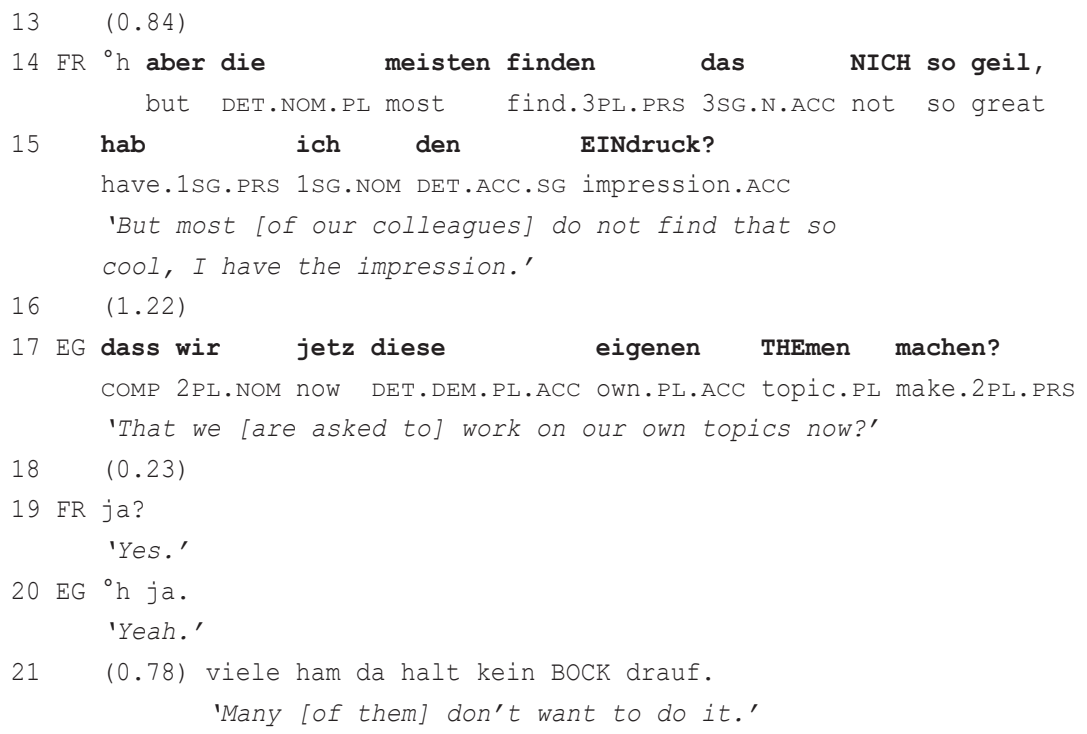

EG and FR are talking about the editorial meetings of the newspaper for which they work. EG mentions that there are many 'open' topics on the agenda (i.e., topics that the writers have chosen themselves) and that one colleague, Elif, is putting a lot of energy into working on many of them (1. 1-12). FR states aber die meisten finden das NICH so geil, hab ich den EINdruck? ('But most [of our colleagues] don't find that so cool, I have the impression.' 1. 14-15). The rising intonation indicates that she expects EG to affiliate with her. A pause follows, which can be taken to indicate that it is not clear whether FR is referring to the existence of 'open' topics (1. 1) or to Elif's efforts to deal with them (1. 4 and 12). EG then produces the complement clause dass wir jetz diese eigenen THEmen machen? ('That we [are asked to] work on our own topics now?', 1. 17) as a check of understanding. ${ }^{29}$ FR confirms EG's interpretation with ja? ('yes', 1. 19) with a rising contour. This again pursues EG's response, which she finally delivers (1. 20-21).

In the example, the complement clause is not a collaborative completion (as in Günthner's [2015: 44] example for a 'free-standing' dass-clause that fulfils the projection of another speaker's matrix clause). ${ }^{30}$ Here, the first speaker's clause only retrospectively becomes a matrix clause, because it has been syntactically, prosodically, semantically, and pragmatically complete. The complement clause is

29. For understanding-checks with es in the matrix clause see Günthner (2015: 52ff.), and with das in the matrix clause see Günthner (2013: 232ff., 2015: 55).

30. The expletive pronoun in the matrix clause in Günthner's example is es, not das. Comparable cases with the demonstrative seem possible introspectively, although our collection does not contain any. 
not projected and performs an action of its own. This is also true for the complement clause used as a self-repair (produced as an answer to a question) in (9). In contrast, in the cases that are not co-constructed, it is disputable whether the complement clause performs a separate action, that is, if 'specification' counts as such (see Section 5).

\section{Discussion}

Our analyses have shown that the right dislocation construction is a conventional pattern of spoken German: Prosodically, it can occur both as a coherently produced whole and it can be produced in two chunks, that is, separate prosodic units which index the potentially independent status of the first clause and the two actions that they accomplish. The interactively constructed cases make especially clear that each clause can accomplish an action of its own (the complement clause can, for example, be a repair initiation or a repair as in (9) and (10)). In the cases that are not co-constructed, the matrix clause performs a complete action independently before the complement clause is added. It remains debatable whether the complement clause merely continues that action or whether '(re-)specification' is an independent action. What speaks in favor of the independent action status is that specifications of potentially ambiguous pronominal references frequently occur as independent main clauses as well (see e.g., Excerpt (5), 1. 5- $6^{31}$ ). The right-dislocation construction thus is one grammaticalized way to produce the two actions of asserting (or, more specifically, for example, assessing or asking a question) and specifying reference as successive chunks of a multi-unit turn (see Couper-Kuhlen \& Thompson, 2008 for a comparable view on the English extraposition construction).

The right dislocation pattern is very productive-a great variety of verbs are used in this construction. In contrast to what Günthner (2009) has found for extraposition, there is no tendency towards the formulaicity of the matrix clause. While many of them have epistemic, evidential or evaluative semantics, eventdescribing verbs are used as well (e.g., das erledigt das LAbel; dass die uns bei der GEma registrieren. 'The label handles this for us, that they register us with GEMA.'; FOLK_E_00044_T_01, c1007). Yet the tendency to contain verbs with 'subjective' semantics is common to all matrix clause constructions (see Section 2); it simply arises from the fact that many complement-taking predicates have meanings expressing attitudes towards propositional referents.

31. Lines 5-6 of Excerpt (5): dann MACHT er das auch nich; ' $h$ dann GIBT er das auch keinem andern. 'Then he won't do that. Then he won't give it [your topic] to anyone else.' 
The actions performed by the matrix clause are accordingly diverse as well, as the examples have shown. Questions and assessments make up important parts of the collection, but are on the whole not more frequent than other actions. ${ }^{32}$ Thus, as has been found for right-dislocated NPs in French by Horlacher (2015) and Pekarek Doehler et al. (2015), matrix clauses of right-dislocated complement clauses in German are frequently used for, but not specifically tied to, assessments. ${ }^{33}$ Rather, the bi-clausal right dislocation pattern is a very flexible construction, whose overarching characteristics ('chunking' and 'linking', incremental (re-) specification of meaning, and potentially retrospective and prospective reference) can be used in the service of various actions.

\section{Conclusion}

The combination of matrix clause and right-dislocated complement clause is a linking construction that has retrospective and prospective properties. The first clause performs a backward-oriented action and the second clause (re-)specifies reference, but also often includes lexical material that prospectively serves as a link to the content of further, upcoming TCUs. The construction is thus particularly suited for linking parts of multi-unit turns.

The construction is conventionalized and thus can be used as a whole. Yet it often results from online planning and expansions, taking advantage of structural latencies of the emerging turn structure (Auer, 2015), in particular the potential to reinterpret the (originally anaphoric) pronoun. Because of its bi-partite structure, the construction allows for the incremental production of meaning, that is, a successive realization of an action (for example, a statement, assessment, or question) and a specification/disambiguation of complex propositional or meta-pragmatic references, which can yield a summary, a change of perspective, or a topic expansion. The construction creates cohesion and accommodates emergent interactional contingencies of structuring multi-unit turns, securing understanding or (more or less strategic) perspective shifts. From the point of view of information structure, it adheres to Chafe's (1994) 'one new idea' constraint, presenting only one new concept or referent per clause and often also per intonation unit. Thus, it is part of a large family of bi-clausal constructions (such as extrapositions and pseudo-clefts; see e.g., Günthner \& Hopper, 2010) that have been described in the literature as produced in separate chunks that perform separate functions and accommodate the temporality of talk-in-interaction.

32. Among the 93 cases in the collection are 21 assessments and 10 questions.

33. The other sequential functions described as typical in the literature on French are not frequent in our collection. 


\section{References}

Ahrenholz, Bernt. 2007. Verweise mit Demonstrativa im gesprochenen Deutsch. Grammatik, Zweitspracherwerb und Deutsch als Fremdsprache. Berlin: de Gruyter. https://doi.org/10.1515/9783110894127

Altmann, Hans. 1981. Formen der „Herausstellung“im Deutschen: Rechtsversetzung, Linksversetzung, freies Thema und verwandte Konstruktionen. Tübingen: Niemeyer. https://doi.org/10.1515/9783111635286

Auer, Peter. 1991. Vom Ende deutscher Sätze. Zeitschrift für germanistische Linguistik 19, 139-157. https://doi.org/10.1515/zfgl.1991.19.2.141

Auer, Peter. 1996. On the prosody and syntax of turn-continuations. In Elizabeth Couper-Kuhlen \& Margret Selting (Eds.), Prosody in conversation. Interactional studies. (pp. 57-100). Cambridge: Cambridge University Press. https://doi.org/10.1017/CBO9780511597862.004

Auer, Peter. 2005. Projection in interaction and projection in grammar. Text 25(1), 7-36. https://doi.org/10.1515/text.2005.25.1.7

Auer, Peter. 2007. Why are increments such elusive objects? An afterthought. Pragmatics 17(4), 647-658. https://doi.org/10.1075/prag.17.4.03aue

Auer, Peter. 2010. Zum Segmentierungsproblem in der Gesprochenen Sprache. InLiSt - Interaction and Linguistic Structures, 49. http://www.inlist.uni-bayreuth.de/issues/49/InList49.pdf

Auer, Peter. 2015. The temporality of language in interaction: Projection and latency. In Arnulf Deppermann \& Susanne Günthner (Eds.), Temporality in interaction (pp. 27-56). Amsterdam: Benjamins.

Averintseva-Klisch, Maria. 2009. Die NP-Rechtsversetzung im Deutschen. Tübingen: Stauffenburg.

Barth-Weingarten, Dagmar. 2011. Double sayings of German JA - more observations on their phonetic form and alignment function. Research on Language and Social Interaction 44(2), 157-185. https://doi.org/10.1080/08351813.2011.567099

Chafe, Wallace L. 1976. Givenness, contrastiveness, definiteness, subjects and topics. In Charles N. Li (Ed.), Subject and topic (pp. 27-55). New York, NY: Academic Press.

Chafe, Wallace. 1994. Discourse, consciousness, and time: The flow and displacement of conscious experience in speaking and writing. Chicago, IL: The University of Chicago Press.

Consten, Manfred, \& Schwarz-Friesel, Monika. 2007. Anapher. In Ludger Hoffmann (Ed.), Handbuch der deutschen Wortarten (pp. 265-292). Berlin: de Gruyter.

Consten, Manfred, Knees, Mareile, \& Schwarz-Friesel, Monika. 2007. The function of complex anaphors in texts: Evidence from corpus studies and ontological considerations. In Monika Schwarz-Friesel, Manfred Consten, \& Mareile Knees (Eds.), Anaphors in text: Cognitive, formal and applied approaches to anaphoric reference (pp. 81-102). Amsterdam: Benjamins. https://doi.org/10.1075/slcs.86.09con

Couper-Kuhlen, Elizabeth, \& Ono, Tsuyoshi (Eds.). 2007. Turn-continuation in cross-linguistic perspective: Introductory remarks. Special Issue of Pragmatics 17(4).

Couper-Kuhlen, Elizabeth, \& Thompson, Sandra A. 2006. You know, it's funny: Eine Neubetrachtung der Extraposition im Englischen. In Susanne Günthner \& Wolfgang Imo (Eds.), Konstruktionen in der Interaktion (pp. 23-58). Berlin: de Gruyter. https://doi.org/10.1515/9783110894158.23 
Couper-Kuhlen, Elizabeth, \& Thompson, Sandra A. 2008. On assessing situations and events in conversation: 'Extraposition' and its relatives. Discourse Studies 10(4), 443-467. https://doi.org/10.1177/1461445608091882

Deppermann, Arnulf, \& Proske, Nadine. 2015. Grundeinheiten der Sprache und des Sprechens. In Christa Dürscheid \& Jan-Georg Schneider (Eds.), Handbuch Satz, Äußerung, Schema (pp. 17-47). Berlin: de Gruyter. https://doi.org/10.1515/9783110296037-003

Du Bois, John W. et al. 1993. Outline of Discourse Transcription. In Jane A. Edwards \& Martin D. Lampert (Eds.), Talking Data: Transcription and Coding in Discourse Research (pp. 45-89). Hillsdale, NJ: Lawrence Erlbaum Associates.

Ford, Cecilia, \& Thompson, Sandra A. 1996. Interactional units in conversation: Syntactic, intonational, and pragmatic resources for the management of turns. In Elinor Ochs, Emanuel A. Schegloff, \& Sandra A. Thompson (Eds.), Interaction and Grammar (pp. 134-184). Cambridge: Cambridge University Press. https://doi.org/10.1017/CBO9780511620874.003

Gallmann, Peter. 2009. Der Satz. In Matthias Wermke, Kathrin Kunkel-Razum, \& Werner Scholze-Stubenrecht (Eds.), Duden - die Grammatik. 8., überarbeitet Auflage. Mannheim: Dudenverlag.

Geluykens, Ronald. 1987. Tails (right dislocations) as a repair mechanism in English conversation. In Jan Nuyts \& Georges De Schutter (Eds.), Getting one's word into line: On word order and functional grammar (pp. 119-129). Dordrecht: Foris.

Golato, Andrea, \& Fagyal, Zsuzsanna. 2008. Comparing single and double sayings of the German response token $j a$ and the role of prosody: A Conversation Analytic perspective. Research on Language and Social Interaction 41(3), 241-270. https://doi.org/10.1080/08351810802237834

Günthner, Susanne. 2009. Extrapositionen mit es im gesprochenen Deutsch. Zeitschrift für germanistische Linguistik 37, 15-47. https://doi.org/10.1515/ZGL.2009.003

Günthner, Susanne. 2013. Vom schriftsprachlichen Standard zur pragmatischen Vielfalt? Aspekte einer interaktional fundierten Grammatikbeschreibung am Beispiel von dass-Konstruktionen. In Jörg Hagemann, Wolf Peter Klein, \& Sven Staffeldt (Eds.), Pragmatischer Standard (pp. 223-243). Tübingen: Stauffenburg.

Günthner, Susanne. 2015. Geteilte Syntax: Kollaborativ erzeugte dass-Konstruktionen. In Alexander Ziem \& Alexander Lasch (Eds.), Konstruktionsgrammatik IV. Konstruktionen als soziale Konventionen und kognitive Routinen (pp. 25-40). Tübingen: Stauffenburg.

Günthner, Susanne, \& Hopper, Paul J. 2010. Zeitlichkeit \& sprachliche Strukturen: Pseudoclefts im Englischen und Deutschen. Gesprächsforschung - Online-Zeitschrift zur verbalen Interaktion 11, 1-28. http://www.gespraechsforschung-online.de/fileadmin/dateien/heft2010/ ga-guenthner.pdf

Horlacher, Anne-Sylvie. 2015. La dislocation à droite revisitée: une approche interactionniste. Louvain-la-Neuve: de boeck. https://doi.org/10.3917/dbu.hcher.2015.01

Keevallik, Leelo. 2011. Pro-forms as projective devices in interaction. Discourse Processes 48, 404-431. https://doi.org/10.1080/0163853X.2011.559150

Ono, Tsuyoshi, \& Thompson, Sandra A. (Eds.). 2012. A cross-linguistic, multi-modal, grammaticization perspective on turn continuation in conversation. Special issue of Discourse Processes 49(3-4).

Pekarek Doehler, Simona, De Stefani, Elwys, \& Horlacher, Anne-Sylvie. 2015. Time and emergence in grammar. Dislocation, topicalization and hanging topic in French talk-in-interaction. Amsterdam: Benjamins. https://doi.org/10.1075/slsi.28 
Proske, Nadine. 2013. Informationsmanagement im gesprochenen Deutsch. Eine diskurspragmatische Untersuchung syntaktischer Strukturen in Alltagsgesprächen. Heidelberg: Winter.

Ross, John Robert. 1967. Constraints on variables in syntax. Ph.D. dissertation, MIT.

Schegloff, Emanuel A. 1996. Turn organization: One intersection of grammar and interaction. In Elinor Ochs, Emanuel A. Schegloff, \& Sandra A. Thompson (Eds.), Interaction and Grammar (pp. 52-133). Cambridge: Cambridge University Press. https://doi.org/10.1017/CBO9780511620874.002

Schmidt, Thomas. 2014. The research and teaching corpus of spoken German - FOLK. In Proceedings of the Ninth conference on International Language Resources and Evaluation (LREC'14). Reykjavik, Iceland: European Language Resources Association (ELRA).

Selting, Margret et al. 2009. Gesprächsanalytisches Transkriptionssystem 2 (GAT 2). Gesprächsforschung - Online-Zeitschrift zur verbalen Interaktion 10, 353-402. http://www. gespraechsforschung-ozs.de/heft2009/px-gat2.pdf

Uhmann, Susanne. 1993. Das Mittelfeld im Gespräch. In Marga Reis (Ed.), Wortstellung und Informationsstruktur (pp. 313-354). Tübingen: Niemeyer. https://doi.org/10.1515/9783111658469.313

Zifonun, Gisela, Hoffman, Ludger, \& Strecker, Bruno (Eds.). 1997. Grammatik der deutschen Sprache. Berlin: de Gruyter. 